\title{
The effect of antiviral substance 6-(2-morpholin-4-yl-ethyl)-6H-indolo [2,3-b]quinoxaline upon biomarkers of inflammation
}

\author{
G. V. Antonovych ${ }^{1}$, N. M. Zholobak ${ }^{1}$, M. O. Shibinska ${ }^{2}$, M. Ya. Spivak ${ }^{1}$ \\ ${ }^{1}$ D. K. Zabolotny Institute of Microbiology and Virology, NAS of Ukraine \\ 154, Academika Zabolotnoho Str., Kyiv, Ukraine, 03680 \\ ${ }^{2}$ O. V. Bogatsky's Physico-chemical Institute, NAS of Ukraine \\ 86, Lustdorfskaya dor., Odessa, Ukraine, 65080 \\ g.antonovych@gmail.com
}

\begin{abstract}
Aim. To investigate changes in pro-inflammatory status of laboratory rats after introduction of antiviral substances with interferon-inducing action: 6-(2-morpholin-4-yl-ethyl)-6H-indolo[2,3-b]quinoxaline and tilorone. Methods. MCP-1 content, blood leukocyte counts and functional activity of phagocytes were measures using flow cytometry techniques. Complement content was determined in microtest based upon hemolysis of sensitized erythrocytes. Results. Both oral and intraperitoneal applications of the substances were characterized by an elevation in monocytic counts, potentiated metabolic reserve of phagocytic cells, increased MCP-1 and complement content in serum. In contrast to tilorone, after introduction of 6-(2-morpholin-4-yl-ethyl)-6H-indolo[2,3-b]quinoxaline substantial raise in circulating neutrophil counts and their phagocytic activity was not determined, while MCP-1 and complement responses were significantly lower compared to reference substance. Conclusion. Although both substances are IFN-inducers with pluripotent immunostimulatory action, the tested derivative was characterized by a less pronounced elevation of complement activity, MCP-1 content and neutrophil counts. This implies that application of 6-(2-morpholin-4-yl-ethyl)-6H-indolo[2,3-b]quinoxaline can strengthen innate antiviral resistance with minimized risks of potential autoimmunological adverse effects.
\end{abstract}

Ke y w o r d s: 6H-indolo[2,3-b]quinoxalines, inflammation, interferon, MCP-1, complement.

\section{Introduction}

Indolo[2,3-b]quinoxalines belong to a group of low molecular substances with a tetracyclic heteroaromatic core. A wide range of biological activity has been reported for different derivatives of this group, incuding the anti-inflammatory, anti-cancerogenic, antifungal effects, and in case of planar configuration - the antiviral action and antitumor activity. In recent years we have searched for new antiviral substances among several newly-synthesized and previously known indoloquinoxalines. One of them - 6-(2-morpholin-4yl-ethyl)-6H-indolo[2,3-b]quinoxaline (hereinafter S1) - has demonstrated the low toxicity, prolonged interferon (IFN) induction in vivo, antiviral activity in vitro in both prophylactic and therapeutic application schemes, as well as an ability to potentiate the functional activity of murine peritoneal cells [1,2]. Such spectrum of biological properties allowed us to consider S1 an immunomodulating substance. To further characterize the compound it was expedient to examine in more detail the changes caused by it in the immune system of laboratory animals, with particular focus on the pro-inflammatory biomarkers. Tilorone hydrochloride, a potent IFN-inducer in rodents, was chosen as a reference drug.

\section{Materials and Methods}

\section{Substances and dosage}

S1 and tilorone were kindly provided by Dr Sergey Lyakhov (Department of Medical Chemistry, A.V. Bo-

(C) 2015 G. V. Antonovych et al.; Published by the Institute of Molecular Biology and Genetics, NAS of Ukraine on behalf of Biopolymers and Cell. This is an Open Access article distributed under the terms of the Creative Commons Attribution License (http://creativecommons.org/licenses/by/4.0/), which permits unrestricted reuse, distribution, and reproduction in any medium, provided the original work is properly cited 
gatsky Physico-Chemical Institute, NAS of Ukraine). The substances were administered orally and intraperitoneally (i.p.) as solutions in sterile water according to the conventional methods. The optimal doses were determined in the preliminary studies of IFN-induction and were as follows: for tilorone $125 \mathrm{mg} / \mathrm{kg}$ orally, $12.5 \mathrm{mg} / \mathrm{kg}$ i.p.; for S $1-60 \mathrm{mg} / \mathrm{kg}$ orally, $10 \mathrm{mg} / \mathrm{kg}$ i.p. An additional $30 \mathrm{mg} / \mathrm{kg}$ dose was used for the oral administration of S1, since it was able to induce IFN in a wider concentration range than the reference drug.

\section{Animals and sampling}

To evaluate the effect of studied substances upon the immune system, the changes in the following parameters were measured: immune cell counts in circulating blood, phagocytic and metabolic activity of neutrophils and monocytes, complement hemolytic activity, levels of monocyte chemotactic protein-1 (MCP-1). The experiment was performed on 40-day old male Wistar rats weighing 130-170 g. Group formation and marking of animals were held for 2 days prior to the substance administration in order to minimize the stress. The animals were kept in large cages with free access to water and standard diet. Handling procedures were conducted according to European Convention for the Protection of Vertebrate Animals (Strasbourg, 2006). Each group consisted of $7-10$ rats.

The blood samples were collected from the carotid arteries on I, III, VII and X day after the substances administration. Part of the blood, not less than $3 \mathrm{ml}$, was gathered into tubes with sodium heparin («Vacuette», Austria); remaining blood was collected in the centrifuge tubes for serum. Purified serum was frozen within 30 minutes after the blood collection and stored at $-20{ }^{\circ} \mathrm{C}$.

\section{Measurement techniques}

The numbers of lymphocytes, monocytes and granulocytes were measured relatively to Flow-Count standardized fluorospheres using a EPICS XL flow cytometer (Beckman Coulter). Preliminary staining of monocytes with HIS48 antibody (BD PharMingen) was performed to distinguish them from lym- phocytic pool, whereas granulocytes were differentiated from other cells by their light scattering properties. The phagocytic activity and the intensity of oxidative burst inside phagocytes were assessed in whole blood environment using a $\mathrm{pH}$-rodo test system (Life Technologies). Prior to the measurements, erythrocytes were lysed with Q-Prep solutions (Beckman Coulter).

The determination of MCP-1 levels in serum was also performed using the FlowCytomix (eBioscience) test system according to the manufacturer's instructions. The level of complement activity was established in a microtest [3] based on the hemolysis of sensitized sheep erythrocytes.

\section{Statistics and representation}

Statistical analysis was performed in Microsoft Excel 2010. The same program was used along with OriginPro 8.1 for graphical representation of the results. Due to the small sampling size, a non-parametrical Mann-Whitney test was applied to assess the differences between animal groups. The differences
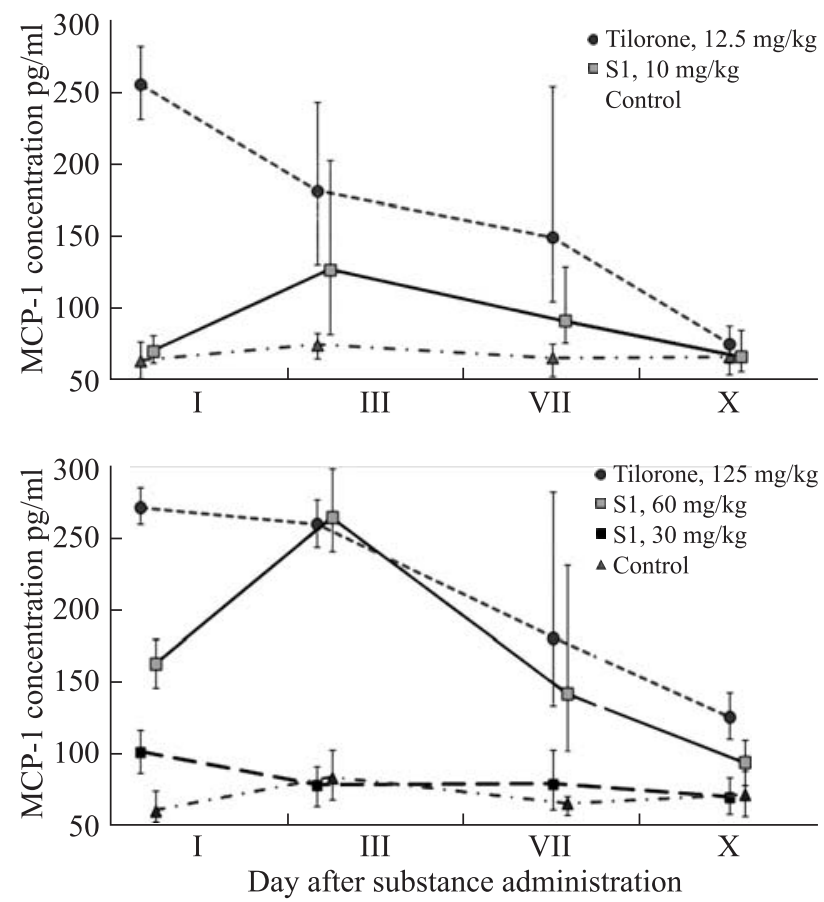

Fig. 1. Effect of the intraperitoneal and oral substance administration upon the level of monocyte chemotactic protein-1 

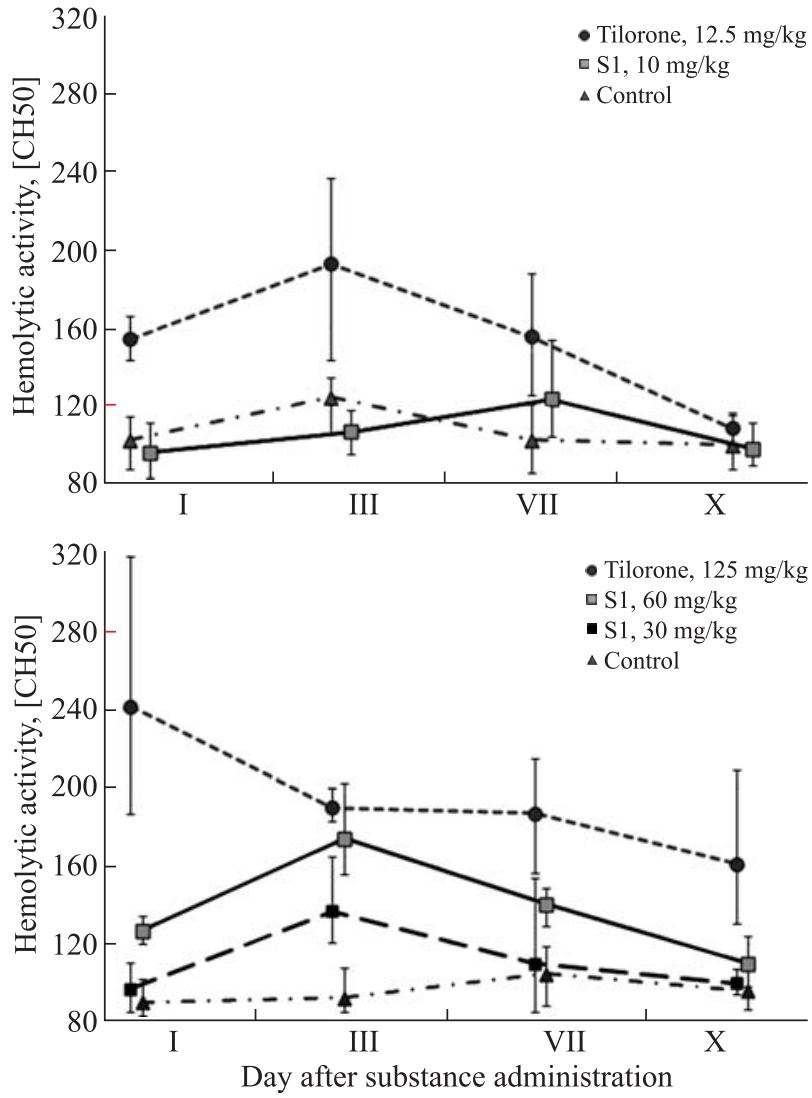

Fig. 2. Complement activity after the intraperitoneal and oral administration of the substances

were considered significant at $\mathrm{P}<0.05$. The results are presented as medians, error bars denote the absolute maximum and minimum.

\section{Results and discussion}

\section{Effect upon MCP-1 levels}

The monocyte chemotactic protein-1 is a major chemokine that determines the extent to which a monocyte/macrophage link is involved in the overall immune response [4]. It was shown to be more potent than other macrophage chemoattractants [5]. Apart from the recruitment of monocytes to the sight of inflammation and stimulation of their proliferation, MCP-1 also attracts T-cells, plays a part in the polarization of Th0 lymphocytes into Th1/Th2 subpopulations, and affects the activity of NK- and memory T-cells [6]. Most MCP-1 producing cells are also ab- le to produce IFN and other cytokines. That is why after introduction of immunomodulatory substances, the changes in this chemokine level were expected. Interestingly, however, that in case of S1 a maximum MCP-1 level was detected only on the third day after the substance administration (Fig. 1), whereas tilorone was characterized by a more classical dynamics: a peak was observed on the first day of monitoring period, with subsequent gradual decrease. These trends were characteristic of both oral- and intraperitoneal administration routes. On day $\mathrm{X}$ of monitoring, the differences between tested and control animal groups were not significant, therefore the data are not provided.

Up-regulation of MCP-1, observed in the animals treated with $\mathrm{S} 1$, presumably has a secondary nature, taking into account short lifespan of the chemokine in vivo and the above described dynamics of its content. In our experiments on mice [2] it was previously shown that IFN production reaches maximum on the third day after the administration of S1, which coincides in time with the peak MCP-1 levels. However, although interferons, especially IFN- $\gamma$, are known to induce the MCP-1 synthesis, other factors are probably involved in the MCP triggering.

The results, obtained on the animals that received i.p. injections, were characterized by a high level of variation, which did not allow us to state significant differences between the substances starting from the third day of monitoring. However, estimating the median and maximum MCP-1 levels, detected in the animals stimulated with $\mathrm{S} 1$ and tilorone, we can assume a more pronounced chemokine potentiation by the reference drug. When administered orally, a significantly lower MCP-1 production was noted for a $30 \mathrm{mg} / \mathrm{kg}$ dose of S1, although the IFN-inducing effect of this smaller dose is comparable to that of 60 $\mathrm{mg} / \mathrm{kg}$ dosage and tilorone (data not provided).

\section{The activity of complement system}

The complement system is a collection of soluble proteins that circulate in blood in a non-activated form, playing a part in both native and adaptive immunity. Our understanding of its role in the antiviral defense has slightly increased in the recent years. In 
addition to the opsonization and agglutination of virions, the lysis of virus-infected cells and the chemotactic functions, it was shown that complement components $\mathrm{C} 3 \mathrm{a}, \mathrm{C} 5 \mathrm{a}$ and their inactive precursor $\mathrm{C} 3$ also play a role in the activation of cytotoxic $\mathrm{T}$ lymphocytes [7, 8], NK-, and B-cells [9, 10], as well as in the prolongation of their lifespan. The method, used by us for assessing the activity of complement system, does not allow characterization of the changes in its individual components. However, the obtained results (Fig.2) in general indicate an ability of the studied compounds to increase the overall complement hemolytic activity.

The activation effect caused by tilorone in both routes of administration was significantly higher than that of S1 on the first and third days of monitoring. S1, administered intraperitoneally, did not lead to a substantial rise of the complement activity relative to the control animal group. Moreover, the oral application of this substance in $30 \mathrm{mg} / \mathrm{kg}$ dose was characterized by a lower hemolytic activity compared to tilorone. The dynamics of complement activity resembled that of the MCP-1 production: maximal levels were detected mostly on the third day of observation, except for the oral tilorone application, characterized by an earlier peak. At the end of monitoring period the differences between all animal groups were insignificant.

\section{Changes in immune cell counts}

The numbers of circulating lymphocytes, monocytes and neutrophils in the blood were established on day VII of observation. Both administration methods of the reference drug and indoloquinoxaline derivative did not lead to significant changes in the number of lymphocytes, therefore corresponding data are not provided. Under tilorone influence neutrophils were significantly increased relative to the control (Fig. 3, 4) and in case of the oral administration - relatively to $\mathrm{S} 1$ as well. The increased numbers of circulating monocytes were observed for both drugs, regardless of administration route. However, the oral administration of $\mathrm{S} 1$ in $30 \mathrm{mg} / \mathrm{kg}$ dose did not affect the number of monocytes, or the
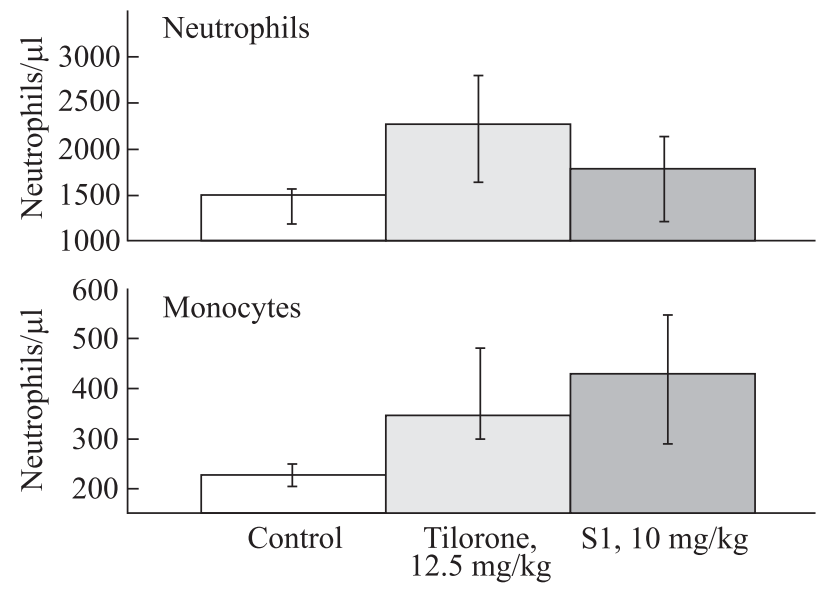

Fig. 3. Number of circulating phagocytes on the day VII after the intraperitoneal substance administration
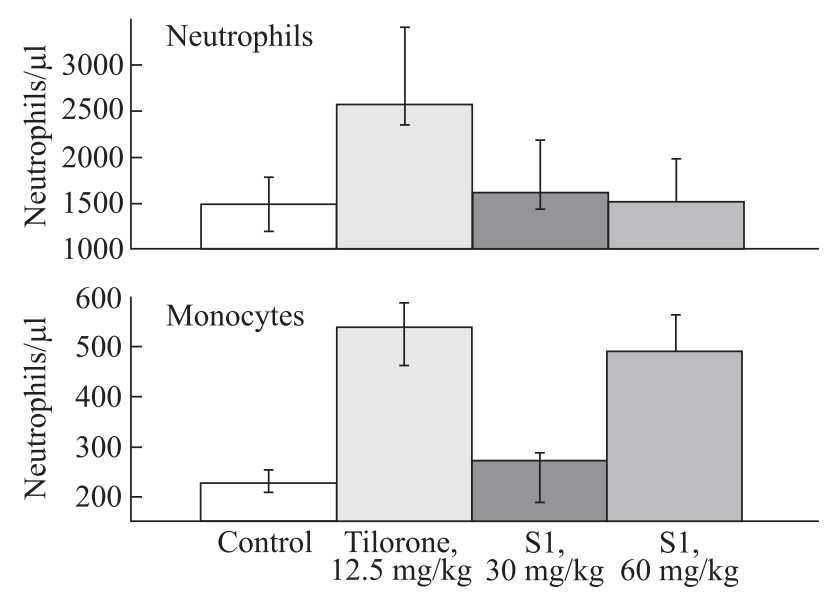

Fig. 4. Number of circulating phagocytes on the day VII after the oral substance administration

effect lasted less than seven days. It should be noted, that in rodents a great percentage of monocytes is deposited in the spleen and can be recruited into the blood flow more effectively, than in humans [11]. The recruitment of neutrophils also took place, but had a limited range.

In general, the results obtained resemble a typical response to an immune-modulating drug. The changes in absolute lymphocytic counts are rare and occur only after serious immunological disturbances, operative interventions or oncological conditions. For these reasons we did not expect to reveal them. On the other hand, neutrophils and monocytes are much 

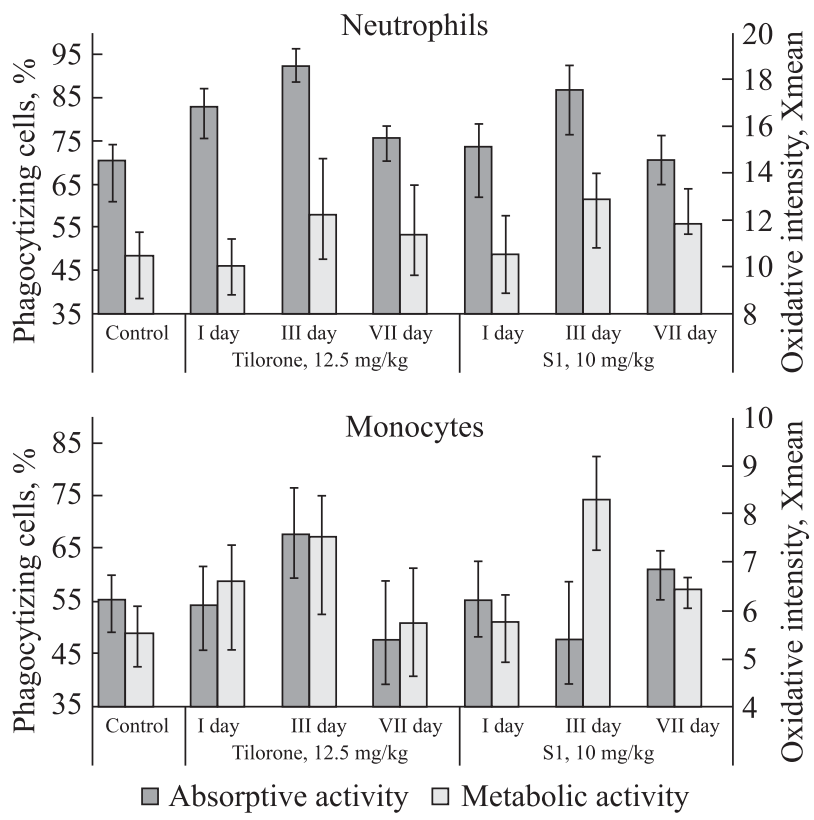

Fig. 5. Functional activity of circulating phagocytes after the intraperitoneal injection of substances

Note: The left vertical axis corresponds to the cellular absorption activity, the right Y-axis displays the oxidative activity
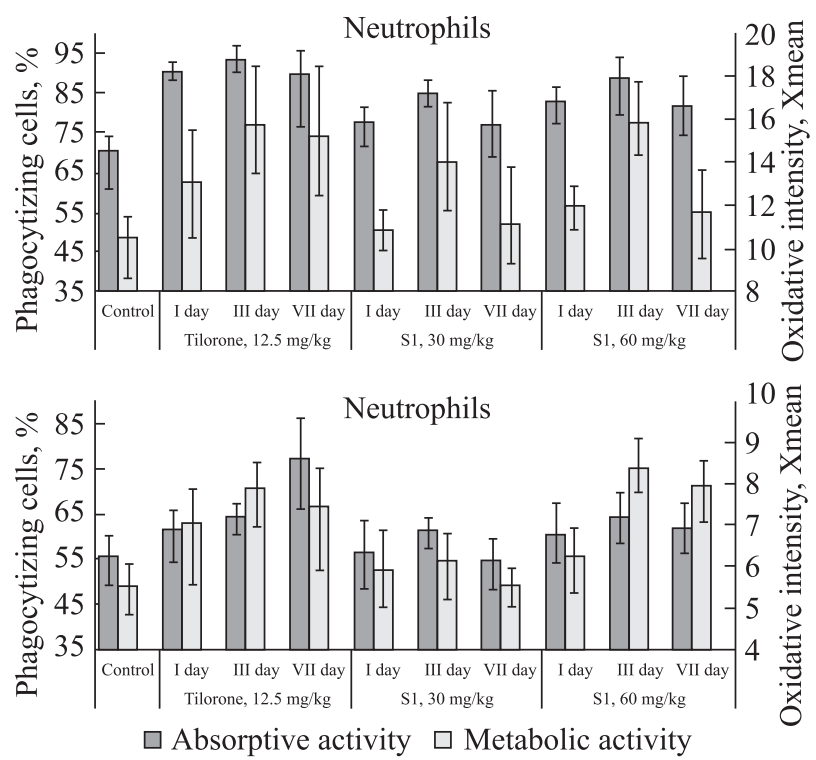

Fig. 6. Functional activity of circulating phagocytes after the oral substance administration

Note: The left vertical axis corresponds to the cellular absorption activity, the right $Y$-axis displays the oxidative activity more labile, mobile cells. An increase in their numbers is a common consequence of the cytokine boost. Thus, the oral treatment of rats with tilorone, which was proved to be more efficient than $\mathrm{S} 1$ at enhancing complement activity and MCP-1 levels, logically led to higher neutrophil counts. The same dependency can be marked between two oral doses of S1: a smaller $30 \mathrm{mg} / \mathrm{kg}$ dose is characterized by a weaker effect upon the MCP-1 and complement system, causing a minimal change in cell number. Interestingly, however, i.p. injection of S1 leads to a significant increase of monocyte counts relative to the control, although corresponding treatment did not alter the complement activity and only poorly elevated the MCP-1 content.

\section{Influence upon functional activity of phagocytes}

An increase in phagocytic activity of neutrophils relative to control was observed in both methods of tilorone administration and lasted from the first to the seventh day of monitoring period (Fig. 5, 6). A similar effect of the tested indoloquinoxaline after i.p. injection was less pronounced, and in case of oral administration required a bigger dose to manifest. These results correlate with indicators of neutrophil metabolic activity: oxidative burst was significantly intensified on day III and VII after oral tilorone administration, whereas for $\mathrm{S} 1$ such potentiation was more brief and observed only in case of a higher oral dose.

The studied substances mainly did not alter the percentage of phagocytizing monocytes. A rise in monocytic absorptive capacity was notable only on the day VII of observation in the animals, treated orally with tilorone $(\mathrm{P}<0,05)$. In other animal groups the changes in phagocytic activity of monocytes were not significant, however the substances managed to potentiate the intensity of their oxidative burst. In particular, under the $60 \mathrm{mg} / \mathrm{kg}$ oral dose of S1, as well as after the intraperitoneal injection of this substance, the monocyte metabolic activity was enhanced on the III and VII days of observation (Fig. 5, 6). A similar effect of the reference drug was notable only on the third day for both routes of administration. 
The effect of antiviral substance 6-(2-morpholin-4-yl-ethyl)-6H-indolo[2,3-b]quinoxaline upon biomarkers of inflammation

E. coli bacteria, used as an object for phagocytosis in this experiment, were not antibody-opsonized. That is why the above-described rise of the cellular phagocytic activity cannot be linked with the complement system, up-regulated by the studied compounds. However, according to the classical works $[12,13]$ the complement components can modulate the oxidative burst intensity without antibody mediation. Obviously, this parameter is even more dependent upon the MCP-1 content. In this respect it should be noted that although S1 induced a lower MCP-1 production than tilorone, it managed to potentiate the metabolic activity of monocytes as effectively as the reference drug. The ability of S1 to stimulate the oxidative intensity was demonstrated earlier on murine peritoneal macrophages [2]. In this study S1, administered intraperitoneally, prompted a faster and more pronounced tetrazolium reduction by macrophages than a greater tilorone dosage. This may seem not to correlate with observations of the current work, however here a system response of the cells is evaluated instead of a local one, and circulating monocytes were studied instead of mature macrophages.

\section{Conclusions}

The application of immuno-stimulating agents with the purpose to strengthen the antiviral defense mechanisms as a rule leads to the pluripotent effects. 6-(2Morpholin-4-yl-ethyl)-6H-indolo[2,3-b]quinoxaline as a low molecular substance is likely to react with the membrane and the cytoplasmic pattern recognition receptors or even bind to DNA, as was shown for some structurally similar indoloquinoxalines [14]. Such activity can result in several vectors of intracellular signaling and subsequent effects. The described changes in the immunological parameters of the animals, treated with tilorone and S1, are interconnected and altogether indicate the activation of innate immunity. From one sight, this can be considered as a positive effect, but from the other point of view all the studied parameters are referred to as the pro-inflammatory markers. A pathological role of complement and MCP-chemokines is well recognized in atherosclerosis, myocarditis, systemic lupus erythematosus, whereas the elevated activity of phagocytes is most undesirable during certain pulmonary conditions and after organ transplantation [15].

These facts do not imply strictly a negative character of the up-regulated immunological parameters. In fact, they all remained within- or close to normal physiological range. The potentiated hemolytic activity indicates an elevated content of the non-activated complement components, which in the normal conditions are unable to cause a direct physiological action. The intensification of oxidative burst is another reserve that the organism acquired but does not normally use. It is a depiction of the increased metabolic resources required to form the reactive oxygen species (ROS), which would not be engaged until necessary. Therefore, all possibly undesirable biological effects that can be mediated by the complement system and ROS are not likely to manifest without preliminary individual auto-immunological predisposition. MCP-1, in turn, is too potent as a chemokine to be left unnoticed. Its elevation in case of S1, however, was relatively brief. An increase in monocyte and neutrophil counts has a more lasting effect, especially taking into account their high absorptive potential.

According to the work [16], human, murine and rat monocytes can be divided into two main populations:pro-inflammatory and classical. They pass their level of inflammatory inclination to macrophages, into which they differentiate. In mice all monocytes that are recruited into the blood flow from the bone marrow are $\mathrm{Ly} 6 \mathrm{C}+$ (analog of human $\mathrm{Cd} 14+$ CD16+ cells), demonstrating the secretion of ROS, TNF $\alpha$, nitric oxide, IL-1 $\beta$, large amounts of type 1 interferon and high phagocytic capacity. The expression of Ly6C+ later diminishes, turning cells into classical Ly6C- monocytes with an anti-inflammatory cytokine profile [17]. The stimulatory signals, caused by $\mathrm{S} 1$ and tilorone, can prevent this process, causing a long-time inflammatory predisposition in some percent of phagocytes. This consequence to certain extent is inevitable for all medications that induce the endogenous cytokine production. Nevertheless, potential adverse effects in patients with allergic and immunological disorders should be taken into account during the subsequent pre-clinical and clinical testing of S1. 
An important observation is that the different doses and application routs of S1 can lead to a stronger or weaker elevation of the inflammatory markers. In particular, a lower oral dose $-30 \mathrm{mg} / \mathrm{kg}$, which in our previous experiment induced the prolonged IFN production, was characterized by minimal influence upon the numbers and function of phagocytizing cells in blood, the complement activity and MCP-1 content. It means that the tested indoloquinoxaline can potentiate the antiviral immunity with minimal inflammatory effects.

\section{REFERENCES}

1. Shibinskaya MO, Lyakhov SA, Mazepa AV, Andronati SA, Turov AV, Zholobak NM, Spivak NY. Synthesis, cytotoxicity, antiviral activity and interferon inducing ability of 6-(2aminoethyl)-6H-indolo[2,3-b]quinoxalines. Eur J Med Chem. 2010;45(3):1237-43

2. Antonovych GV, Zholobak NM, Lyakhov SA, Shibinska MO, Andronati SA, Spivak MY. Dose-dependent IFN-stimulating and immunomodulating properties of $6 \mathrm{H}$-indolo[2,3-B] quinoxaline derivatives. Mikrobiol Z. 2012;74(4):79-86.

3. Inglis JE, Radziwon KA, Maniero GD. The serum complement system: a simplified laboratory exercise to measure the activity of an important component of the immune system. Adv Physiol Educ. 2008;32(4):317-21.

4. Yadav A, Saini V, Arora S. MCP-1: chemoattractant with a role beyond immunity: a review. Clin Chim Acta. 2010;411 (21-22):1570-9.

5. Uguccioni M, D’Apuzzo M, Loetscher M, Dewald B, Baggiolini $M$. Actions of the chemotactic cytokines MCP-1, MCP-2, MCP-3, RANTES, MIP-1 alpha and MIP-1 beta on human monocytes. Eur J Immunol. 1995;25(1):64-8.

6. Deshmane SL, Kremlev S, Amini S, Sawaya BE. Monocyte chemoattractant protein-1 (MCP-1): an overview. J Interferon Cytokine Res. 2009;29(6):313-26.

7. Suresh M, Molina H, Salvato MS, Mastellos D, Lambris JD, Sandor M. Complement component 3 is required for optimal expansion of CD8 T cells during a systemic viral infection. J Immunol. 2003;170(2):788-94.

8. Kim AH, Dimitriou ID, Holland MC, Mastellos D, Mueller YM, Altman JD, Lambris JD, Katsikis PD. Complement C5a receptor is essential for the optimal generation of antiviral CD8+ T cell responses. J Immunol. 2004;173 (4): 2524-9.

9. Qing X, Koo GC, Salmon JE. Complement regulates conventional DC-mediated NK-cell activation by inducing TGF- $\beta 1$ in Gr-1+ myeloid cells. Eur J Immunol. 2012;42(7):1723-34.

10. Carroll MC. The role of complement in B cell activation and tolerance. Adv Immunol. 2000;74:61-88.

11. Swirski FK, Nahrendorf $M$, Etzrodt $M$, Wildgruber $M$, Cortez-Retamozo V, Panizzi P, Figueiredo JL, Kohler RH, Chu- dnovskiy A, Waterman P, Aikawa E, Mempel TR, Libby P, Weissleder R, Pittet MJ. Identification of splenic reservoir monocytes and their deployment to inflammatory sites. Science. 2009;325(5940):612-6.

12. Goldstein IM, Roos D, Kaplan HB, Weissmann G. Complement and immunoglobulins stimulate superoxide production by human leukocytes independently of phagocytosis. $J$ Clin Invest. 1975;56(5):1155-63.

13. Goldstein IM, Feit F, Weissmann G. Enhancement of nitroblue tetrazolium dye reduction by leukocytes exposed to a component of complement in the absence of phagocytosis. J Immunol. 1975;114(1 Pt 2):516-8.

14. Wilhelmsson LM, Kingi $N$, Bergman J. Interactions of antiviral indolo[2,3-b]quinoxaline derivatives with DNA. J Med Chem. 2008;51(24):7744-50.

15. The biology and pathology of innate immunity mechanisms. Eds. Keisari Y, Ofek I. Advances in experimental medicine and biology, Vol 479. Kluwer Academic, 2002. 242 p.

16. Strauss-Ayali D, Conrad SM, Mosser DM. Monocyte subpopulations and their differentiation patterns during infection. J Leukoc Biol. 2007;82(2):244-52.

17. Yang J, Zhang L, Yu C, Yang XF, Wang H. Monocyte and macrophage differentiation: circulation inflammatory monocyte as biomarker for inflammatory diseases. Biomark Res. 2014;2(1):1.

\section{Вплив 6-(2-морфолін-4-іл-етил)-6Н-індоло [2,3-b]хіноксаліна на біомаркери запалення}

Г. В. Антонович, Н. М. Жолобак, М. О. Шибінська, М. Я. Співак

Мета. Дослідити вплив 6-(2-морфолін-4-іл-етил)-6Н-індоло [2,3-b]хіноксаліна (антивірусної сполуки з інтерферон-індукуючою дією) на про-запальний статус лабораторних щурів. Методи. Концентрація МСР-1, кількість лейкоцитів в крові та функціональна активність фагоцитів визначали цитофлюориметричними методами. Активність системи комплементу оцінювалась в мікротесті на основі гемолізу сенситизованих еритроцитів. Результати. Застосування перорального та парентерального способу введення сполук супроводжувалось збільшенням кількості моноцитів, потенціонуванням метаболічного резерву фагоцитуючих клітин, підвищенням вмісту МСР-1 і компонентів комплементу в сироватці крові. Після введення 6-(2-морфолін-4-іл-етил)-6Н-індоло[2,3-b] хіноксаліну достовірного збільшення кількості циркулюючих нейтрофілів або їх фагоцитарної активності не спостерігалось, в той час як рівні МСР-1 і компонентів комплементу були значно нижчими, ніж у препарату порівняння - тилорону. Висновки. ІХоча обидві сполуки є індукторами ІФН 3 плюрипотентною імуностимулюючою дією, тестоване похідне призводило до менш вираженого підвищення активності комплементу, нижчого вмісту МСР-1 та кількісті нейтрофілів. Даний факт свідчить на користь того, що застосу- 
The effect of antiviral substance 6-(2-morpholin-4-yl-ethyl)-6H-indolo[2,3-b]quinoxaline upon biomarkers of inflammation

вання 6-(2-морфолін-4-іл-етил)-6Н-індоло[2,3-b]хіноксаліну для посилення неспецифічного антивірусного імунітету супроводжуватиметься нижчим ризиком розвитку побічних аутоімунологічних реакцій

К л юч о в і с л о в а: 6Н-індоло[2,3-b]хіноксалін, запалення, інтерферон, МСР-1, комплемент.

\section{Влияние 6-(2-морфолин-4-ил-этил)-6Н-индоло [2,3-b]хиноксалина на биомаркеры воспаления}

Г. В. Антонович, Н. М. Жолобак, М. О. Шибинская, Н. Я. Спивак

Цель. Изучить влияние 6-(2-морфолин-4-ил-этил)-6Н-индоло[2,3-b]хиноксалина (антивирусного соединения с интерферон-индуцирующим действием) на про-воспалительный статус лабораторных крыс. Методы. Концентрация МСР-1, количество лейкоцитов в крови и функциональная активность фагоцитов определялись цитофлюориметрическими методами. Активность системы комплемента оценивали в микротесте, основанном на гемолизе сенситизированных эритроцитов. Результаты. Как пероральный, так и парентеральный способы введения соединений приводили к увели- чению количества моноцитов, потенционированию метаболического резерва фагоцитирующих клеток, повышению содержания МСР-1 и компонентов комплемента в сыворотке крови. После введения 6-(2-морфолин-4-ил-этил)-6Н-индоло[2,3-b]хиноксалина достоверного увеличения численности циркулирующих нейтрофилов либо их фагоцитарной активности не наблюдалось, в то время как уровни МСР-1 и компонентов комплемента были значительно ниже, чем у препарата сравнения - тилорона. Выводы. Хотя оба соединения представляют собой индукторы ИФН с плюрипотентным иммуностимулирующим действием, тестируемое производное приводило к менее выраженному повышению активности комплемента, меньшему содержанию МСР-1 и количеству нейтрофилов. Данный факт свидетельствует о том, чтоприменение 6-(2-морфолин-4-ил-этил)-6Н-индоло[2,3-b] хиноксалина для усиления неспецифического противовирусного иммунитета будет нести более низкие риски развития побочных аутоиммунологических реакций.

Кл юч е в ы е с л о в а: 6Н-индоло[2,3-b]хиноксалины, воспаление, интерферон, МСР-1, комплемент.

Received 07.06.2015 